\title{
Quality of deep frying oils and fats used in street-fairs in Goiânia, Brazil
}

\author{
Poliana Cristina Mendonça FREIRE ${ }^{1 \star}$, Lorrany Cristina Boel LOBO², \\ Giselle da Silva FREITAS 3 , Tânia Aparecida Pinto de Castro FERREIRA²
}

\begin{abstract}
Fried foods are widely consumed in Brazil and their quality depends on the oil or fat they are fried. Qualitative (physical chemistry indices) and quantitative measurements (fry-life oil or fat until disposal, oil turnover, type of oil or fat and amount and type of fried foods) and associations were performed. We applied a structured form and collected $60 \mathrm{~mL}$ of frying oil or fat in each of the 70 fried food stands of 15 street-fairs in Goiânia, Brazil. All samples were suitable in the quantity of free fat acids $(<0.9 \%$ oleic acid), one was inadequate to peroxide value $(>10 \mathrm{mEq} / \mathrm{kg})$ and $1 / 3$ was unsuitable to polar compounds $(<25 \%)$. The majority $(62 \%)$ use temperature up to the allowed $\left(180^{\circ} \mathrm{C}\right)$. Approximately 250 units of products are fried in at least one day in $42 \%$ of the fried food stands. Soybean oil is used in the majority $(94 \%)$ of fried food stands and the fry-life is of 6 hours $(60 \%)$ or a day of work/sale. The nonconformity of the content of total polar compounds in fried foods had significant association with frying time and the conformity of acidity had significant relationship with frying time by a chi-square test. All other associations were not significant. A fry-life of oil or fat up to 6 hours can avoid the excess of polar compounds in the frying medium and protect the quality of fried foods.
\end{abstract}

Keywords: food quality; frying process; street-food; food-service; peroxide value; total polar compounds.

\section{Introduction}

Consumers prefer the sensorial qualities of fried foods as flavor, appearance, and texture. The consumption of fried foods, mainly pastries is a deeply rooted Brazilian custom. Many people attend fairs solely to consume fried pastries and snacks, as well as coffee, soda and other cost-effective products that can be eaten quickly (BAURU, 2007) and special fairs at Goiânia, Goiás, Brazil, have become an important part of Goiás popular culture, selling cloths and fried foods as salty snacks and pastries (GOIÂNIA, 2010).

The quality of pastries and other fried snacks depends not only on the sanitary conditions in which they are produced, maintained and ordered, but also on the quality of the oil or fat in which they are deep-fried. The frying oil or fat quality influences oil absorption and types of by-products and residues absorbed by food. The type of food being fried also influences the oil or fat fry-life (FREIRE; MANCINI-FILHO; FERREIRA, 2013). Changes in oil and its assessment through the frying cycle of oil or fat used are studied in this paper.

The oil quality monitoring in food service uses quality indicators based on quality attributes as hour of use, smoke evolution, foam height and changing of the original color or by measuring quality variables as percentage of free fatty acids, peroxide value, $\mathrm{p}$-anisidine levels, total polar compounds (TPCs) and temperature. However, due to the complexity of the process, no single method can entirely measure the deterioration of oils in the frying process (PRISTOURI; BADEKA; KONTOMINAS, 2010). Some punctual diagnostics has already been performed about the oil quality and quality monitoring of oil or fat used in food service in several studies (STIER, 2004; BERTANHA et al., 2009; BANSAL et al., 2009; JUÁREZ et al., 2011; OSAWA et al., 2012; DAMY; JORGE, 2003; JORGE; JANIERI, 2004). They used rapid methods based in color. Others (DOBARGANES; VELASCO; DIEFFENBACHER, 2000; RYWOTYCKI, 2003; OSAWA; GONÇALVES; GRIMALDI, 2006) draw comparisons with the official method of determination of CPT proposed by Waltking and Wessels (1981). The oil analysis test results were highly correlated with the values determined by the official methodology (high performance liquid chromatography) of determining TPCs which is an analytical procedure that provides a sensitive and reliable determination of compounds in fats and oils and differentiates major groups of components included in the polar fraction. Nevertheless, some rapid kits are based on oil /fat color change from raw to darken. The rapid tests and mainly, the color oil alone, is not adequate to determine the acceptability of frying oils. Different frying oils and food being fried in these oils will darken the oil at different rates (ORTHOEFER; COOPER, 1996).

This study proposed to determine the association between quantitative and qualitative aspects of the quality of the oil and fat used in deep frying salty snacks and pastries at street-fairs in Goiânia, Brazil.

${ }^{1}$ Federal Institute of Education, Science and Technology, Rua 75, 46, Centro, CEP 74055-110, Goiânia, GO, Brazil, e-mail: pocrismf@yahoo.com.br

2 Nutrition Faculty, Federal University of Goiás - UFG, Goiânia, GO, Brazil

${ }^{3}$ Division of Food Sanitation of Municipal Health Surveillance, Goiânia, GO, Brazil

${ }^{*}$ Corresponding author
} 


\section{Materials and methods}

\subsection{Sampling}

This is a cross-sectional, descriptive and exploratory study, approved by the Ethics Committee of the Federal University of Goiás, under protocol number 288/2010.

There are 30 special street-fairs registered in Municipal Economic Development Agency of Goiânia. We covered 50\% of this population, i.e., were studied 15 bigger street-fairs, as determined by number of visitors and size. These 15 streetfairs represent $50 \%$ of registered trade fairs by the Municipal Economic Development Agency. At each of these fairs, information was collected through interviews with all the owners of the fried food stands of street-fairs that discarded the deep frying oil or deep frying shortening on the collection day. The average was 4 fried food stands per street-fair.

We chose to focus on the study of deep frying oil or fat at the time of disposal and factors affecting the fry-life. The collection of oil and/or fat of the fried-food stands was punctual, i.e., collected only once.

\subsection{Qualitative assessment of oil or fat frying}

It was applied a structured form to all the fried food stands to identify the qualitative and interfering factors on the quality of the frying oil or fat, investigate the oil or fat fry-life and to characterize how has been done the frying process. The form presented questions as type of frying, type and amount of food fried in the same frying medium, type of oil or fat used, replacement of oil or fat, type of equipment used for frying; storage form during use and overnight, time of use of the oil or fat until disposal and what is the final destination.

\subsection{Sampling of oils and fats}

The oils or fat frying used at the fryers were collected on a single day after at least 6 hours of use.

This work was conducted in partnership with the Municipal Sanitary Surveillance Agency of Goiânia, Goiás, Brazil. The researchers who collected oil/fat samples were accompanied by Food Division inspectors.

We collected $60 \mathrm{~mL}$ of oil or fat at the time of deep frying, using a stainless steel scoop and a glass funnel. Samples were transferred to an amber glass and transported in a cooler with ice sheets to the food laboratory and stored at $-22{ }^{\circ} \mathrm{C}$ for no more than one month until analysis was completed. Before being stored under freezing temperatures, all samples were filtered. Samples were thawed using refrigeration for 24 hours prior to analysis.

\subsection{Quantitative analysis of oils and fats}

\section{Temperature}

At the time of collection the temperature of the oil or fat was measured in ${ }^{\circ} \mathrm{C}$ using an infrared thermometer with laser sights and a range of -60 to $+500^{\circ} \mathrm{C}$ (AKSO Electronic Products, Model AK 32, Brazil).

\section{Total polar compounds}

The TPCs percentage was obtained with a Testo Oil Tester (Testo 270, Testo do Brasil Instrumentos de Medição, Campinas, Brazil). The samples were placed in an amber glass at the time of collection to ensure that the oil/fat remained above $40{ }^{\circ} \mathrm{C}$ as required for this analysis. When the rod of Testo 270 is immersed in oil, after an adaptation time of approximately 10 seconds, its sensor measures the dielectric constant, i.e., the electrical conductivity of these compounds. This value is expressed as a TPCs percentage (STIER, 2004).

\section{Percentage of free fatty acids}

Percentage of free fatty acids was determined using the AOCS Official Method Ca 5a-40 (AMERICAN..., 2004) in triplicate, and expressed as the percentage of oleic acid in the sample.

\section{Peroxide value}

The peroxide value was determined using the AOCS Cd 8-53 (AMERICAN..., 2004) in triplicate, and expressed in $\mathrm{mEq} / \mathrm{kg}$ of the sample.

\section{p-anisidine level}

The $p$-anisidine level was determined using the AOCS Official Method Cd 18-90 (AMERICAN..., 2004) in triplicate, and expressed in anisidine numbers.

\section{Parameters used}

The limits adopted for the use of frying oil or frying fat classified as nonconforming or conforming were frying temperature below $180{ }^{\circ} \mathrm{C}$, as established by RDC No. 216 (AGÊNCIA..., 2004a), TPCs below 25\%, and less than $0.9 \%$ of free fatty acids expressed as oleic acid as recommended by Technical Report No. 11 (AGÊNCIA..., 2004b). For the peroxide value, the maximum value of $10 \mathrm{mEq} / \mathrm{kg}$ established by RDC No. 270 (AGÊNCIA..., 2005) was adopted. This is the only document that establishes national standards of quality and identity for refined vegetable oils. For frying oils/fats, there is no national standard peroxide value. Thus, in this study we adopted $15 \mathrm{meq} / \mathrm{kg}$ as the maximum value of this index as recommended (FIRESTONE; STIER; BLUMENTHAL, 1991; MONFERRER; VILLALTA, 1993; CODEX..., 1993).

\subsection{Statistical analysis}

Descriptive statistics (absolute and relative frequency) was applied to analyze the qualitative variables that characterized the process of frying and a chi-squared test for the associate variables (time of use before disposal, oil type, amount and type of deep-fat frying of snacks with the physical and chemical measures) with a $\mathrm{p}$ value of $<0.05$ considered statistically 
significant. For this analyses, we used the statistical program STATA, version 9.0 (STATACORP, 2011).

\section{Results and discussion}

\subsection{Frying process}

Most fried food stands use soybean oil for frying (Table 1). Soybean oil is widely used in household frying or deep-fat frying in Brazil, given the large supply and the low cost of this product (OSAWA; GONÇALVES; MENDES, 2010), as observed by Jorge and Lopes (2003) in a study conducted in São José do Rio Preto, Brazil. In Salvador, Brazil, soybean oil was generally used for frying or deep-fat frying in markets, rotisseries, bakeries, restaurants and industrial kitchens (CAMILO et al., 2010). Shortening was more likely to be used in fast food restaurants. The selection of frying oil for a particular application requires a balance approach with oil or fat fry-life, eating qualities, product appearance, specific product requirements, cost and easy for handling (DON BANKS, 1996). In the present work, the soybean oil showed to be the most preferred frying medium used in the free-stand fryers.

Slightly more than half of the fried food stands used a discontinuous frying process (Table 1). Oil that was continuously heated had better quality than those oils used in a deep frying process, even at high temperatures or under constant temperature oscillations (MEHTA; SWINBURN, 2001).

In the continuous frying process, is created steam that covers the surface of the oil or fat, it is important to prevent oil come into contact with atmospheric oxygen (CORSINI; JORGE, 2006).

Most free-stand fryers fried only pastries of varied types (cheese, ham, ground beef, pizza, chicken with cheese etc.). Others fried salty snacks such as drumsticks, kebabs or risola. A few number of fried food stands used the same oil or shortening for frying pastries and salty snacks (Table 1). They were careful in not mixing different types of food being fried in the same oil/fat frying. It is worth noting that there may be a decline in product quality when certain foods are fried together and this decline may affect the sensory acceptability by customers (BÁZÁR; SZABÓ; ROMVÁRI, 2010). For example, foods such as onions and fish can add unpleasant odors and flavors to other food products (OSAWA; GONÇALVES; MENDES, 2010). Salty foods can promote ionization. The salt ionizes the water liberated from the product being fried. This ionization provides the opportunity to form soaps when it contacts acidic material resulting from coincidental hydrolysis. Furthermore, salt is a potential source of trace metals known to accelerate oil/fat deterioration.

Lipids present in the foods, principally in salty snacks studied (pastries), contributes both to desirable and undesirable flavors. Among the major compounds of odor and flavor, stands out the 9-hydroperoxide. Flavor and odor of this compound were described as deep-fried odors.

Since foods release water, the longer the oil is used in frying the greater is the possibility of hydrolytic degradation. The loss of oxidative stability of oil is due to the oxidation of lipids (CORSINI; JORGE, 2006).

The most noticeable change in the oil or fat during use is the darkening. Many compounds of food (as carbohydrates, phosphates, sulfur compounds, and trace metals) react with oil/ fat or their breakdown products, contributes to color formation. The rate of color formation can be influenced by the type of food being fried, e.g., vegetables produce less darkening than meats because the source of color development is the Maillard

Table 1. Profile of the frying process used in fried food stands, Goiânia, Brazil, 2011 (fried food stands studied, $\mathrm{N}=50$ ).

\begin{tabular}{|c|c|c|}
\hline Variables & $\begin{array}{l}\text { Absolute } \\
\text { frequency } \\
(\mathrm{N})\end{array}$ & $\begin{array}{c}\text { Relative } \\
\text { frequency } \\
(\%)\end{array}$ \\
\hline \multicolumn{3}{|l|}{ Type of oil and/or fat used } \\
\hline $\begin{array}{l}\text { Hydrogenated vegetable fat } \\
\text { (Shortening) }\end{array}$ & 1 & 2.0 \\
\hline Soybean oil & 47 & 94.0 \\
\hline Cottonseed and sunflower oil & 2 & 4.0 \\
\hline \multicolumn{3}{|l|}{ Type of frying } \\
\hline Continuous & 22 & 44.0 \\
\hline Discontinuous & 28 & 56.0 \\
\hline \multicolumn{3}{|l|}{ Fried foods } \\
\hline Pastries & 35 & 70.0 \\
\hline Salty snacks & 13 & 26.0 \\
\hline Pastries and salty snacks & 2 & 4.0 \\
\hline \multicolumn{3}{|l|}{$\begin{array}{l}\text { Amount of food fried in the same oil } \\
\text { and/or fat (und) }\end{array}$} \\
\hline$<100$ & 14 & 28.0 \\
\hline 100 to 250 & 21 & 42.0 \\
\hline 251 to 500 & 8 & 16.0 \\
\hline$>500$ & 7 & 14.0 \\
\hline \multicolumn{3}{|l|}{ Equipment type } \\
\hline Electric frying pan & 15 & 30.0 \\
\hline Electric kettle & 28 & 56.0 \\
\hline Gas frying pot & 7 & 14.0 \\
\hline \multicolumn{3}{|l|}{ Form of storage } \\
\hline Pot fryer/Electric fryer capped & 3 & 6.0 \\
\hline Pot fryer/Fryer uncapped & 47 & 94.0 \\
\hline \multicolumn{3}{|l|}{ Overnight storage form } \\
\hline Pot fryer/Electric fryer capped & 20 & 40.0 \\
\hline Pot fryer/Electric fryer uncapped & 0 & -- \\
\hline Not applicable & 30 & 60.0 \\
\hline \multicolumn{3}{|l|}{ Replenishment at the same day of use } \\
\hline Yes & 24 & 48.0 \\
\hline Not & 26 & 52.0 \\
\hline \multicolumn{3}{|l|}{ Duration of use before disposal } \\
\hline$<6$ hours & 30 & 60.0 \\
\hline 6-12 hours & 18 & 36.0 \\
\hline$>12$ hours & 2 & 4.0 \\
\hline \multicolumn{3}{|l|}{ Disposal destination } \\
\hline Donated & 2 & 4.0 \\
\hline Sold & 5 & 10.0 \\
\hline Soap Production & 43 & 86.0 \\
\hline
\end{tabular}


reaction. Besides that, the food being fried may produce volatiles that interact with the frying oil /shortening and contributes to their darkening.

The frying process is influenced by other factors, including not only the nature of the fried food but also its quantity. In this study, the most popular fried-food stands fried up to 250 units of products in the same oil or shortening before disposing it. The highest quantity was recorded in the fried food stand selling salty snacks (Table 1).

During the day, most of the fried-food stands kept their fryer equipment uncovered. If the oil/shortening was used for more than one day, the equipment was capped (Table 1). The oxidation process can be facilitated and intensified by light and air (CORSINI; JORGE, 2006). Thus, even during use, the oil/ fat should be protected from these two environmental factors.

In half of the fried food stands, the oil/shortening has not been replaced to cover the oil or shortening lost by the absorption of food being fried (Table 1). The quantity of oil absorbed and necessary to be replaced (oil/fat turnover) is a good indicator of how much stress the oil /shortening is subjected in daily operation. Turnover is one of several important factors that influence the quality of the frying oil/fat (DON BANKS, 1996).

These results were similar to 13 fast food restaurants in Campinas city, Brazil, in which only one restaurant did not perform the oil replacement (OSAWA; GONÇALVES; MENDES, 2010). The addition of new oil is a common practice to make up the griddle/pan and make up for the amount absorbed by the fried food and can decrease the formation of CPT, triglycerides and free fatty acids in the oil/fat frying (ARAÚJO, 2008) and interfere with the results of quality control of this oil/fat. The amount of frying oil /fat that should be used is related to the initial quantity, composition, size and shape of the food being fried (CAMILO et al., 2010).

In a study conducted in Salvador, Brazil, Camilo et al. (2010) took samples of oil or fat frying from 90 food establishments, including bars, cafes and restaurants. They observed that the highest percentage of establishments used soybean oil for up to four days and those restaurants used the oil/shortening for the longest period of time before disposal, until the maximum fry-life oil/shortening.

The majority of fried-food stands reported that their discarded frying oil/shortening is used to make soap to clean the utensils (ladle, pot, dishes, cutlery etc.) that are brought to the markets (Table 1). The National Health Surveillance Agency condemns the use of hand-manufactured cleaning products that have not been approved by the Ministry of Health to clean utensils and equipment that come into contact with food (AGÊNCIA..., 2004a).

\subsection{Physical and chemical measures}

Frying oil or fat changes with the use, from fresh through its optimum state to a degraded condition. An overview of the chemical reactions that occur during frying can be found in Freire, Mancini-Filho and Ferreira (2013). The physical and chemical changes that occur in oils /fats during the frying process are because it takes place at high temperatures and in the presence of air and water from food (MACHADO; DOBARGANES; ABRANTES, 2008).

The conforming and nonconforming of the samples of oil/ shortening until the maximum fry-life oil in relation to physical and chemical quality measures is presented as a percentage in Table 2, with the exception of $\mathrm{p}$-anisidine value.

All samples were within an acceptable range for percentage of free fatty acids, with values ranging from $0.19 \%$ to $0.80 \%$. The observed data are a consequence of new oil added during frying process, which dilutes these values (MENDONÇA et al., 2008). Similar data have also been observed in other regions of Brazil. Tavares et al. (2007) evaluated the quality of commercial fats and oils for frying in Santos city, Brazil; only 9 out of 50 samples evaluated showed unsatisfactory results for percentage of free fatty acids. Jorge and Janieri (2004) studied the percentage of free fatty acids of soybean oil used in frying at a University Restaurant, which practices oil replacement. They observed values of acidity ranging from $0.11 \%$ to $0.36 \%$ after 15 hours of frying; the oil/fat was therefore deemed compliant.

For peroxides, the values ranged from 0.76 to $10.54 \mathrm{mEq} / \mathrm{kg}$, and only one sample was not conforming to this parameter (Table 2). It is worth noting that the peroxide value is not only a good indicator to assess the degree of oxidation of oils and fats but it is also an important indicator of oxidation and rancidity in foods (GUZMÂN et al., 2011), although it does not provide information on secondary oxidation products (SORIANO; MOLTÓ; MAÑES, 2002). As the samples were analyzed on the day of disposal, the peroxide value had likely peaked and subsequently declined.

For this reason, to quantify the oxidation of secondary compounds we determined values of $\mathrm{p}$-anisidine. This is a method used to determine secondary products of lipid oxidation, detecting mainly 2 -alkenal. The anisidine number is defined as 100 times the optical density measured at 350 $\mathrm{nm}$ in a $1 \mathrm{~cm}$ cuvette solution containing $1 \mathrm{~g}$ of oil in $100 \mathrm{~mL}$ of reagent and solvent mixture. The peroxides present in the oxidized fat or oil, animal fat or vegetable oil are transient intermediates that decompose at various carbonyl compounds and other compounds, especially 2,4-dienais and 2-alkenal in the presence of $\mathrm{p}$-anisidine in acidic medium. Among the 50 samples analyzed, the lowest observed value was 6.50 and the highest 98.30. When comparing these values with the frying time, the lowest value was found in a sample of oil/fat used for

Table 2. Percentage of conforming and nonconforming of physical and chemical properties of deep frying oil and fat (Number of stands) ( $\mathrm{N}=50)$, Goiânia, Brazil, 2011.

\begin{tabular}{lcccccc}
\hline \multirow{2}{*}{$\begin{array}{c}\text { Physical and chemical } \\
\text { measures }\end{array}$} & \multicolumn{2}{c}{ Conforming } & & \multicolumn{2}{c}{ Non-conforming } \\
\cline { 2 - 3 } \cline { 5 - 6 } \cline { 5 - 6 } & \multicolumn{2}{c}{ Frequency } & & \multicolumn{2}{c}{ Frequency } \\
\hline Acidity (\% oleic acid & 50 & 100 & & 0 & 0 \\
Peroxide value (mEq/kg) & 49 & 98 & & 1 & 2 \\
TPCs $(\%)$ & 37 & 74 & & 13 & 26 \\
Temperature $\left({ }^{\circ} \mathrm{C}\right)$ & 19 & 38 & & 31 & 62 \\
\hline
\end{tabular}


6 hours, while the highest in a sample, with 18 hours of use. Sunisa et al. (2011), studying the process of frying poultry meat in palm oil, associating temperature and frying time, obtained p-anisidine values ranging from 1.02 to 66.44, and the highest values were also found to increase with the frying time, similar to our study.

Ahmad Tarmizi, Niranjan and Gordon (2013) investigated changes in anisidine under the effect of frying oils combined with air after application to the vacuum frying, obtaining values of $\mathrm{p}$-anisidine between 40 and 100 . These authors also concluded that the amount of $\mathrm{p}$-anisidine gradually increased with time of frying. It is a fact indicating that in the first hours of use, the oxidation reaction is already occurring and primary products (peroxides, hydroperoxides, conjugated dienes, hydroxides and ketones) are formed and degraded, thus producing secondary products (epoxides, compounds volatile and non-volatile) obtained by cleavage and rearrangement of peroxides (GOMES; CAPONIO; DELCURATOLO, 2003).

Most samples of deep frying oil or shortening showed TPCs levels below 25\% (Table 2). Those samples with values that exceed the recommended TPCs levels were all soybean oil samples; however, only three free-standing fryers used other types of oil/fat (hydrogenated vegetable fat or shortening, sunflower and cottonseed oil). A recent study by Juárez et al. (2011), monitoring the quality of soybean oil, sunflower oil and shortening after frying, used the Testo 265 to determine TPCs levels and found that the worst values were observed in soybean oils. Soybean oil was among the worst when compared with sunflower oil (28.5 and 25.8\%, respectively, after 31.5 hours of deep-frying). Generally the dielectric constant depends on the oil type, water content, amount of oil leached from food being fried, and the polar materials (ORTHOEFER; COOPER, 1996).

Given the high percentage of nonconforming between the physical and chemical measurements, these data were associated with the temperature (Table 2). Most of the samples were above $180{ }^{\circ} \mathrm{C}$, and sample temperature ranged from 129 to $210{ }^{\circ} \mathrm{C}$.

A similar result was observed by Tavares et al. (2007) in Santos city, Brazil. Therein, 41 stores ( $82 \%$ of the samples) used oil/shortening at temperatures above $180^{\circ} \mathrm{C}$. The range of 160 to $180{ }^{\circ} \mathrm{C}$ is recommended as the best range to fry foods because under higher temperatures the oil/fat deteriorates more rapidly, and at lower temperatures, the product absorbs more fat/oil. It should be noted that increasing the frying temperature from $180{ }^{\circ} \mathrm{C}$ to $215^{\circ} \mathrm{C}$ causes a considerable increase in the rates of thermal degradation and oxidation (BANSAL et al., 2009; ALADEDUNYE; PRZYBYLSKI, 2009). For most owners of fried-food stands, there is the misconception that the higher the temperature, the better the frying process. In addition, although deep-fryers pans or griddles had thermostats, they often were not used properly or were defective.

In an attempt to understand the effect of qualitative variables (amount of fried snacks, frying oil/fat type and time of fry-use) on the quantitative variables (temperature and physicalchemical measurements - TPCs, acidity and peroxide value), we examined the association between the measures by a chi-squared test. It is presented the results of association of the physical and chemical parameters classified as conforming or nonconforming according to the recommended values and the amount of fried foods and with the time of frying (Table 3); and with the type of frying and type of oil/fat (Table 4 ). We observed no significant $p$ values; thus, from the samples studied it cannot be established the optimal number of snacks that should be fried in the same oil/fat, when oil should be disposed, the recommended type of frying (continuous or discontinuous) or what type of oil or fat is most suitable for the frying process under study.

Nevertheless, by associating the duration of oil/frying fat before disposal and physical-chemical measurements was observed a significant relationship between TPCs and acidity ( $p$ values $<0.05$ ); that is, the longer the frying time before disposal (mainly between 6 and 12 hours), the higher concentration of free fatty acids and polar compounds produced due to auto-oxidation and hydrolysis reactions. The Frying time had significant effects on free fatty acid content and dielectric property. Free fatty acid content increases significantly with increasing frying time. The dielectric property was strongly correlated with frying time of oil samples (ZIAIIFAR et al., 2008).

Table 3. Association between physical and chemical conforming or nonconforming and the amount of food fried and fry-life of oil or shortening used, Goiania, Brazil, $2011(\mathrm{~N}=50)$.

\begin{tabular}{|c|c|c|c|c|c|c|c|c|c|c|}
\hline \multirow{2}{*}{$\begin{array}{c}\text { Physical and chemical } \\
\text { measures }\end{array}$} & \multicolumn{6}{|c|}{ Amount of food fried (units) } & \multicolumn{4}{|c|}{ Use before disposal (hours) } \\
\hline & $<100$ & $\geq 100$ to $\leq 250$ & 251 to 500 & $>500$ & $\mathrm{~N}(\%)$ & p-value & $<6$ & $\geq 6 \mathrm{a} \leq 12$ & $>12$ & p-value \\
\hline TPCs (\%) & & & & & & 0.89 & & & & 0.02 \\
\hline Conforming $(<25 \%)$ & 10 & 15 & 6 & 6 & $37(74)$ & & 25 & 12 & 0 & \\
\hline Nonconforming $(>25 \%)$ & 4 & 6 & 2 & 1 & $13(26)$ & & 5 & 6 & 2 & \\
\hline Acidity (\% oleic acid) & & & & & & 0.17 & & & & 0.00 \\
\hline Conforming $(<0.9 \%)$ & 14 & 21 & 8 & 7 & $50(100)$ & & 30 & 18 & 2 & \\
\hline Nonconforming $(>0.9 \%)$ & 0 & 0 & 0 & 0 & $0(0)$ & & 0 & 0 & 0 & \\
\hline Peroxide value $(\mathrm{mEq} / \mathrm{Kg})$ & & & & & & 0.45 & & & & 0.71 \\
\hline Conforming $(<10 \mathrm{mEq} / \mathrm{Kg})$ & 13 & 21 & 8 & 7 & $49(98)$ & & 29 & 18 & 2 & \\
\hline Nonconforming $(>10 \mathrm{mEq} / \mathrm{Kg})$ & 1 & 0 & 0 & 0 & $1(2)$ & & 1 & 0 & 0 & \\
\hline Temperature $\left({ }^{\circ} \mathrm{C}\right)$ & & & & & & 0.36 & & & & 0.18 \\
\hline Conforming $\left(<180^{\circ} \mathrm{C}\right)$ & 6 & 6 & 5 & 2 & $19(38)$ & & 11 & 6 & 2 & \\
\hline Nonconforming $\left(>180^{\circ} \mathrm{C}\right)$ & 8 & 15 & 3 & 5 & $31(62)$ & & 19 & 12 & 0 & \\
\hline
\end{tabular}


Table 4. Association between physical and chemical conforming or nonconforming of deep frying oil or shortening, Goiania, Brazil, $2011(\mathrm{~N}=50)$.

\begin{tabular}{|c|c|c|c|c|c|c|c|c|}
\hline \multirow{2}{*}{ Physical and chemical measures } & \multicolumn{4}{|c|}{ Type of oil/fat } & \multirow{2}{*}{ p-value } & \multicolumn{2}{|c|}{ Type of deep frying } & \multirow{2}{*}{ p-value } \\
\hline & Soybean oil & Shortening & ${ }^{\star}$ Others & $\mathrm{n}(\%)$ & & Continuous & Discontinuous & \\
\hline TPCs (\%) & & & & & 0.57 & & & 0.26 \\
\hline Conforming $<25 \%$ & 34 & 1 & 2 & $37(74)$ & & 18 & 19 & \\
\hline Nonconforming $>25 \%$ & 13 & 0 & 0 & $13(26)$ & & 4 & 9 & \\
\hline Acidity (\% oleic acid) & & & & & 0.62 & & & 0.62 \\
\hline Conforming $(<0.9 \%)$ & 47 & 1 & 2 & $50(100)$ & & 22 & 28 & \\
\hline Conforming $(<10 \mathrm{mEq} / \mathrm{Kg})$ & 46 & 1 & 2 & $49(98)$ & & 22 & 27 & \\
\hline Nonconforming $(>10 \mathrm{mEq} / \mathrm{Kg})$ & 1 & 0 & 0 & $1(2)$ & & 0 & 1 & \\
\hline Temperature & & & & & 0.24 & & & 0.70 \\
\hline Conforming $\left(<180^{\circ} \mathrm{C}\right)$ & 18 & 1 & 0 & $19(38)$ & & 9 & 10 & \\
\hline Nonconforming $\left(>180^{\circ} \mathrm{C}\right)$ & 29 & 0 & 2 & $31(62)$ & & 13 & 18 & \\
\hline
\end{tabular}

In the city of Goiânia, Brazil, fried-food standsin special fairs has 6:00 hour of workday, usually operating from 16:00 h until 22:00 h. Thus, in relation to time of use of oil/fat before disposal (Table 1), it was observed that $30(60 \%)$ of the stands use the same oil or fat for less than 6 hours, or use it only for a single workday.

One-third of the stands use the same oil/fat for two days (12 hours) before disposal, and two use the same oil/fat for more than 12 hours or use the same oil for frying for three consecutive days ( 18 hours) before replacement; however, these stands also continuously add new oil. A five hours turnover is very rapid and would be sufficient to maintain good quality under most frying conditions (DON BANKS, 1996). Extending the turnover to $12 \mathrm{~h}$ places much more stress on the oil, but good quality could still be maintained in many applications.

Fryer oil quality cannot be maintained in batch fryers with a turnover rate approaching or exceeding $20 \mathrm{~h}$. Even with careful control of all the others aspects of frying (including temperature, moisture, crumbs, and filtration), the oil will deteriorate after a few days of use and need to be replaced. Fresh oil addition will be too slow to maintain oil quality.

The oil turnover should be a primary decisive factor when contemplating any change in the operation of a fryer. Changes that slow the rate of turnover increase oil stress and reduce fry-life, while changes that quicken turnover reduce stress and improve fry-life (DON BANKS, 1996).

The decomposition rate of products in the frying oil is ruled by factors such as the type of food fried, type of oil used, equipment type, frying conditions (time and temperature), frequency of oil replacement, oil quality and presence of antioxidants (CHOE; MIN, 2007; KITA; LISINSKA; GOŁUBOWSKA, 2007; JORGE; LUNARDI, 2004; JORGE et al., 2005; MACHADO et al., 2007). Osawa, Gonçalves and Mendes (2010) found that, even with some set parameters, the frying process is difficult to control and even frying processes conducted in a laboratory are difficult to reproduce. Then, with our results we showed that is necessary to replace all the oil/fat frying used after a workday.

\section{Conclusions}

This was a study of association between the profile of the frying process information and physical and chemical quality of the frying oil/fat. Of all the associations performed we found a negative association between the type of fried food and the type of frying oil or fat used.

The frying time was significantly associated with the content of total polar compounds and free fatty acids.

In this study, the frying fat or oil used followed this conditions: frying pan uncovered; replacement with new oil or fat, shortening used in some cases, frying more than 500 units of food products and in some situations up to frying 3 different types of food in the same oil, should be disposed after 6 hours of use, in order to preserve the health of the consumer. The frying process used by fried food stands in special fairs in Goiânia city, Brazil, utilizes soybean oil with and without replacement during frying; using continuous and discontinuous frying methods; frying up 250 units of food, primarily pastries. These foods are fried in the same oil. The electric frying pans used remain uncovered during the work day, but are capped overnight; disposed oil is used to produce soap.

All samples were within an acceptable range for percentage of free fatty acids and half were within an acceptable range for peroxide value, while for temperature and TPCs, about a half were not within an acceptable range.

There was a positive association between the frying time, TPCs and percentage of free fatty acids. It is recommended that fried-food stands discard the oil / shortening after a workday using, i.e., after 6 hours of use, to ensure its quality and, hence, to protect the consumer health and maintain the quality of fried food.

\section{Acknowledgements}

To financial support from the CAPES (Coordination for the Improvement of Higher Education Personnel) that made possible the purchase of oil and fat analyzer equipment and reagents. 
To the Food Division inspectors of the Goiânia Municipal Health Surveillance who assisted the researchers in obtaining samples and to the street food merchants of stand fairs who participated in the study, they are Alexandra Alves Carvalho Maia, Brunna Silva Andrade, Eduardo Portela Rezende, Fernanda Cristina Pereira Caris, Paulo César Lemes do Prado and Victória Matilde Matos Machado.

\section{References}

AGÊNCIA NACIONAL DE VIGILÂNCIA SANITÁRIA - ANVISA. Resolução RDC n² 216, de 15 de setembro de 2004. Dispõe sobre Regulamento Técnico de Boas Práticas para Serviços de Alimentação. Diário Oficial da República Fedeartiva do Brasil, Brasília, DF, set. 2004a. Disponível em: <http://www.anvisa.gov.br/ alimento/informes>. Acesso em: $20 \mathrm{dez} .2012$.

AGÊNCIA NACIONAL DE VIGILÂNCIA SANITÁRIA - ANVISA. Informe Técnico $\mathrm{n}^{\circ} 11$, de 05 de outubro de 2004. Dispõe sobre Boas Práticas de Fabricação para utilização e descarte de óleos utilizados em frituras. Diário Oficial da República Fedeartiva do Brasil, Brasília, DF, out. 2004b. Disponível em: <http://www.anvisa. gov.br/alimento/informes>. Acesso em: $20 \mathrm{dez} .2012$.

AGÊNCIA NACIONAL DE VIGILÂNCIA SANITÁRIA - ANVISA. Resolução RDC no 270, de 22 de setembro de 2005. Aprova o regulamento técnico para óleos vegetais, gorduras vegetais e creme vegetal. Diário Oficial da República Fedeartiva do Brasil, Brasília, DF, set. 2005. Disponível em: <http://www.anvisa.gov.br/alimento/ informes $>$. Acesso em: 20 dez. 2012.

AHMAD TARMIZI, A. H.; NIRANJAN, K.; GORDON, M. Physicochemical changes occuring in oil when atmospheric frying is combined with post-frying vacuum application. Food Chemistry, v. 136, n. 2, p. 902-908, 2013. PMid:23122143. http:// dx.doi.org/10.1016/j.foodchem.2012.08.001

ALADEDUNYE, F. A.; PRZYBYLSKI, R. Degradation and nutritional quality changes of oil during frying. Journal of the American Oil Chemists' Society, v. 86, n. 2, p. 149-156, 2009.

AMERICAN OIL CHEMISTS' SOCIETY - AOCS. Official methods and recommended practices of the American Oil Chemists' Society. Champaign: American Oil Chemists' Society; 2004.

ARAÚJO, J. M. A. Química de alimentos: teoria e prática. 4. ed. Viçosa: UFV, 2008.

BANSAL, G. J. et al. Analysis of trans fatty acids in deep frying oils by three different approaches. Food Chemistry, v. 116, n. 2, p. 535-541, 2009. http://dx.doi.org/10.1016/j.foodchem.2009.02.083

BAURU. Legislação Municipal. Decreto n 48.172, 2007. Regulamento que dispõe sobre o funcionamento das feiras livres no município de São Paulo. Diário Oficial de Bauru, Bauru, SP, 2007. Ano VII, n. 822, p. 87. Disponível em: <http://www.prefeitura.sp.gov.br>. Acesso em: 26 nov. 2012.

BÁZÁR, G.; SZABÓ, A.; ROMVÁRI, R. NIR based quality control of frying fat samples by means of Polar Qualification System. Food Control, v. 21, n. 7, p. 992-997, 2010. http://dx.doi.org/10.1016/j. foodcont.2009.12.017

BERTANHA, B. J. et al. Avaliação da qualidade de óleos e gorduras de fritura por meio de testes rápidos. Higiene Alimentar, v. 23, n. 172-173, p. 177-182, 2009.

CAMILO, V. M. A. et al. Avaliação da qualidade de óleos e gorduras de fritura em bares, restaurantes e lanchonetes. Revista do Instituto Adolfo Lutz, v. 69, n. 1, p. 91-98, 2010.
CHOE, E.; MIN, D. B. Chemistry of deep-fat frying oils. Journal of Food Science, v. 72, n. 5, p. R77-R86, 2007. PMid:17995742. http:// dx.doi.org/10.1111/j.1750-3841.2007.00352.x

CODEX ALIMENTARIUS COMMISSION. Codex alimentarius, fats, oils and related oroducts. 2. ed. Roma: FAO, 1993. v. 8, 133 p.

CORSINI, M. S.; JORGE, N. Estabilidade oxidativa de óleos vegetais utilizados em frituras de mandioca palito congelada. Ciência e Tecnologia de Alimentos, v. 26, n. 1, p. 27-32, 2006. http://dx.doi. org/10.1590/S0101-20612006000100005

DAMY, P. C.; JORGE, N. Determinações físico-químicas do óleo de soja e da gordura vegetal hidrogenada durante o processo de fritura descontínua. Brazilian Journal of Food Technologynology, v. 6, n. 2, p. 251-7, 2003.

DOBARGANES, M, C.; VELASCO, J.; DIEFFENBACHER, A. Determination of polar compounds, polymerized and oxidized triacylglycerols, and diacylglycerols in oils and fats. Pure and Applied Chemistry, v. 72, n. 8, p. 1563-1575, 2000. http://dx.doi. org/10.1351/pac200072081563

DON BANKS. Food service frying. In: PERKINS, E. G.; ERICKSON, M. D. Deep frying: chemistry, nutrition, and practical applications. Champaign: AOAC Press, 1996. chapt. 12, p. 245-257.

FIRESTONE, D.; STIER, R. F.; BLUMENTHAL, M. M. Regulation of frying fats and oils. Food Technology, v. 45, n. 2, p. 90-4, 1991.

FREIRE, P. C. M.; MANCINI-FILHO, J.; FERREIRA, T. A. P. C. Principais alterações físico-químicas em óleos e gorduras submetidos ao processo de fritura por imersão: regulamentação e efeitos na saúde. Revista de Nutrição, v. 26, n. 3, p. 353-368, 2013. http://dx.doi.org/10.1590/S1415-52732013000300010

GOIÂNIA. Portal da Prefeitura de Goiânia. Feiras Especiais. 22 mar. 2010. Disponível em: <http://www.prefeituragoiania.stiloweb.com. br>. Acesso em: 5 dez. 2012.

GOMES, T.; CAPONIO, F.; DELCURATOLO, D. Non-conventional parameters for quality evaluation of refined oils with special reference to commercial class olive oil. Food Chemistry, v. 83, n. 3, p. 403-408, 2003. http://dx.doi.org/10.1016/S0308-8146(03)00102-X

GUZMÁN, E. et al. Application of low-resolution Raman spectroscopy for the analysis of oxidized olive oil. Food Control, v. 22, n. 12, p. 20362040, 2011. http://dx.doi.org/10.1016/j.foodcont.2011.05.025

JORGE, N.; JANIERI, C. Avaliação do óleo de soja utilizado no restaurante universitário do IBILCE/UNESP. Alimentos e Nutrição, v. 15, n. 1, p. 11-16, 2004.

JORGE, N.; LOPES, M. R. V. Avaliação de óleos e gorduras de frituras coletados no comércio de São José do Rio Preto-SP. Alimentos e Nutrição, v. 14, n. 2, p. 149 -156, 2003.

JORGE, N.; LUNARDI, V. M. Comportamento de óleos poliinsaturados em frituras descontínuas de batatas. Alimentos e Nutrição, v. 15, n. 2, p. 119-124, 2004.

JORGE, N. et al. Alterações físico-químicas dos óleos de girassol, milho e soja em frituras. Química Nova, v. 28, n. 6, p. 947-951, 2005. http:// dx.doi.org/10.1590/S0100-40422005000600003

JUÁREZ, M. D. J. et al. Degradation in soybean oil, sunflower oil and partially hydrogenated fats after food frying, monitored by conventional and unconventional methods. Food Control, v. 22 , n. 12 , p. 1920-1927, 2011. http://dx.doi.org/10.1016/j. foodcont.2011.05.004

KITA, G.; LISINSKA, G.; GOŁUBOWSKA, G. The effects of oils and frying temperatures on the texture and fat content of potato crisps. Food Chemistry, v. 102, n. 1, p. 1-5, 2007. http://dx.doi. org/10.1016/j.foodchem.2005.08.038 
MACHADO, E. R.; DOBARGANES, M. C.; ABRANTES, S. M. P. Alterações dos óleos de palma e de soja em fritura descontínua de batatas. Ciência e Tecnologia de Alimentos, v. 28, n. 4, p. 786-792, 2008. http://dx.doi.org/10.1590/S0101-20612008000400004

MACHADO, E. R. et al. Uncontrolled variables in frying studies: differences in repeatability between thermoxidation and frying experiments. Grasas y Aceites, v. 58, n. 3, p. 283-288, 2007.

MEHTA, U.; SWINBURN, B. A review of factors affecting fat absorption in hot chips. Critical Reviews in Food Science and Nutrition, v. 41, n. 2, p. 133-154, 2001. PMid:11214763. http:// dx.doi.org/10.1080/20014091091788

MENDONÇA, A. A. et al. Alterações físico-químicas em óleos de soja submetidos ao processo de fritura em unidades produtoras de refeição no Distrito Federal. Comunicação Ciências da Saúde, v. 19, n. 2, p. 115-122, 2008.

MONFERRER, A.; VILLALTA, J. La fritura desde un punto de vista práctico. Alimentacion Equipos Tecnologia, v. 12, n. 3, p. 87-91, 1993.

ORTHOEFER, E. T.; COOPER, D. S. Evaluation of used frying oil. In: PERKINS, E. G.; ERICKSON, M. D. Deep frying: chemistry, nutrition, and practical applications. Champaign: AOAC Press, 1996. chapt. 16, p. 285-296.

OSAWA, C. C. J. et al. Stud y of the effectiveness of quick tests based on physical properties for the evaluation of used frying oil. Food Control, v. 26, n. 2, p. 525-530, 2012. http://dx.doi.org/10.1016/j. foodcont.2012.01.008

OSAWA, C. C.; GONÇALVES, L. A. G.; GRIMALDI, R. Emprego do fri-check na avaliação da qualidade de óleos e gorduras de fritura. Higiene Alimentar, v. 20, n. 145, p. 73-79, 2006.

OSAWA, C. C.; GONÇALVES, L. A. G.; MENDES, F. M. Avaliação dos óleos e gorduras de fritura de estabelecimentos comerciais da cidade de Campinas/SP. As boas práticas de fritura estão sendo atendidas? Alimentos e Nutrição, v. 21, n. 1, p. 47-55, 2010.
PRISTOURI, G.; BADEKA, A.; KONTOMINAS, M. G. Effect of packaging material headspace, oxygen and light transmission, temperature and storage time on quality characteristics of extra virgin olive oil. Food Control, v. 21, n. 4, p. 412-418, 2010. http:// dx.doi.org/10.1016/j.foodcont.2009.06.019

RYWOTYCKI, R. Food frying process control system. International Journal of Food Engineering, v. 59, n. 4, p. 339-342, 2003. http:// dx.doi.org/10.1016/S0260-8774(02)00491-0

SORIANO, J. M.; MOLTÓ, J. C.; MAÑES, J. Hazard analysis and critical control points in deep-fat frying. European Journal of Lipid Science and Technology, v. 104, n. 3, p. 174-177, 2002. http://dx.doi.org/10.1002/1438-9312(200203)104:3<174::AIDEJLT174>3.0.CO;2-7

STATACORP. Stata: Release 9. Statistical Software. College Station: StataCorp LP, 2011.

STIER, R. F. Tests to monitor quality of deep-frying fats and oils. European Journal of Lipid Science and Technology, v. 106, n. 11, p. 766-771, 2004. http://dx.doi.org/10.1002/ejlt.200401049

SUNISA, W. et al. Quality changes of chicken frying oil as affected of frying conditions. International Food Research Journal, v. 18, n. 2, p. 615-620, 2011.

TAVARES, M. et al. Avaliação da qualidade de óleos e gorduras utilizados para fritura no comércio da Região Metropolitana da Baixada Santista, estado de São Paulo. Revista do Instituto Adolfo Lutz, v. 66, n. 1, p. 40-44, 2007.

WALTKING, A. E.; WESSELS, H. Chromatographic separation of polar and non-polar components of frying fats. Journal of AOAC, v. 64, n. 6, p. 1329-30, 1981.

ZIAIIFAR, A. M. et al. Review of mechanisms, conditions, and factors involved in the oil uptake phenomenon during the deep-fat frying process. International Journal of Food Science \& Technology, v. 43 , n. 8 , p. $1410-1423,2008$. http://dx.doi.org/10.1111/j.13652621.2007.01664.x 